\title{
Evolution of non-metallic inclusions during heat treatment
}

\author{
Chengsong Liu ${ }^{1,2,{ }^{*}}$ and Bryan Webler ${ }^{2}$ \\ 1 The State Key Laboratory of Refractories and Metallurgy, Wuhan University of Science and Technology, \\ Wuhan 430081, PR China \\ 2 Department of Materials Science and Engineering, Carnegie Mellon University, Pittsburgh, PA 15213, USA
}

Received: 22 February 2020 / Accepted: 18 June 2020

\begin{abstract}
Isothermal heat treatment can not only modify steel microstructure, but also non-metallic inclusions. In this work, heat treatment experiments were conducted between 1373 and $1573 \mathrm{~K}$ (1100 and $1300^{\circ} \mathrm{C}$ ) to study the evolution of inclusion composition, morphology, and size distribution. Results showed that during the heat treatment at 1473 and $1573 \mathrm{~K}\left(1200\right.$ and $\left.1300{ }^{\circ} \mathrm{C}\right)$, two main kinds of inclusions initially in the steel, $\mathrm{CaS}$ and $\mathrm{MgO}-\mathrm{Al}_{2} \mathrm{O}_{3}-\mathrm{CaO}-\mathrm{CaS}$, gradually transformed to ( $\left.\mathrm{Ca}, \mathrm{Mn}\right) \mathrm{S}$ and $\mathrm{MgO}-\mathrm{Al}_{2} \mathrm{O}_{3}-(\mathrm{Ca}, \mathrm{Mn}) \mathrm{S}$ inclusions, and some $\mathrm{MgO}-\mathrm{Al}_{2} \mathrm{O}_{3}-\mathrm{CaO}$ inclusions also transformed to $\mathrm{MgO}-\mathrm{Al}_{2} \mathrm{O}_{3}-(\mathrm{Ca}, \mathrm{Mn}) \mathrm{S}$. At the lowest temperature studied, $1373 \mathrm{~K}\left(1100^{\circ} \mathrm{C}\right)$, little change was observed. No significant changes in number density and area fraction of the measured inclusions were observed, while the average size of inclusions increased after the heat treatment. The extent of transformation of $\mathrm{CaS}, \mathrm{MgO}-\mathrm{Al}_{2} \mathrm{O}_{3}-\mathrm{CaO}-\mathrm{CaS}$ and $\mathrm{MgO}-\mathrm{Al}_{2} \mathrm{O}_{3}-\mathrm{CaO}$ inclusions increased with decreasing inclusion size and higher temperature.
\end{abstract}

Keywords: Non-metallic inclusions / heat treatment / transformation / interfacial reactions

\section{Introduction}

Uncontrolled non-metallic inclusions in steel may have detrimental effects on mechanical properties such as strength, toughness, and ductility [1-6]. Generally, characteristics of the inclusions are modified and optimized by refining slag, calcium treatment or rare earth treatment in molten steel to minimize their harmfulness and eliminate nozzle clogging during casting [7-13]. However, the final inclusions in steel product are not exactly the same as those in the molten steel. Apart from reactions that occur during solidification [14-18], heat treatment processes that modify steel microstructures also can contribute to the transformation of the inclusions [19-23]. The effects of inclusion formation during solidification and the changes during heat treatment must be examined for a complete understanding of how inclusions evolve to their state in the final product. This work focuses on the effects of solid-state transformations occurring during heat treatment.

There have been several studies that investigated these kinds of transformations, though many fewer than those having investigated inclusion evolution in the liquid state. H. Shibata et al. [24] reported that at a low Si concentration in stainless steel, $\mathrm{MnO}-\mathrm{SiO}_{2}$ type inclusions gradually changed into $\mathrm{MnO}-\mathrm{Cr}_{2} \mathrm{O}_{3}$ type inclusions during heat treatment at $1473 \mathrm{~K}\left(1200^{\circ} \mathrm{C}\right)$, while at a high Si content,

\footnotetext{
* e-mail: liuchengsong@wust.edu.cn
}

the $\mathrm{MnO}-\mathrm{SiO}_{2}$ type inclusion was stable after heat treatment. Y.Ren et al. [25] reported similar findings, with $\mathrm{Cr}$ in 304 stainless steel reacting with manganese silicates to form chromite spinels during heat treatment in the range of 1273 to $1473 \mathrm{~K}$ (1000 to $1200^{\circ} \mathrm{C}$ ). A model was developed in that study assuming the rate of transformation was dependent on diffusion of species in the steel to the inclusion, therefore the transformation rate depended strongly on both temperature and inclusion size. K.H. Kim et al. [26] found the equilibrium oxide with Fe-Mn-Si alloy was not a binary compound of $\mathrm{MnO}$ and $\mathrm{SiO}_{2}$ but a ternary compound of $\mathrm{MnO}, \mathrm{SiO}_{2}$, and $\mathrm{FeO}$. After heat treatment at 1673 and $1473 \mathrm{~K}$ ( 1400 and $1200^{\circ} \mathrm{C}$ ), diffusion of oxygen from the oxide to the alloy resulted in new $\mathrm{MnO}-\mathrm{SiO}_{2}$ oxide particles precipitating in the alloy near the interface. W. Choi et al. [27] studied the behavior of non-metallic inclusions in $\mathrm{Al}-\mathrm{Ti}$ deoxidized steels at $1473 \mathrm{~K}\left(1200^{\circ} \mathrm{C}\right)$ with three different steels and argued that $\mathrm{Al}$ and $\mathrm{Ti}$ contents in the steels were critical for the transformation occurrence of $\mathrm{Al}_{2} \mathrm{O}_{3}, \mathrm{Al}_{2} \mathrm{O}_{3}-\mathrm{TiO}_{\mathrm{x}}$ and $\mathrm{TiO}_{\mathrm{x}}$ inclusions to $\mathrm{Fe}-\mathrm{Al}-\mathrm{O}, \mathrm{Fe}-\mathrm{Al}-\mathrm{Ti}-\mathrm{O}$ and $\mathrm{Fe}-\mathrm{Ti}-\mathrm{O}$ inclusions during heat treatment. X.J. Shao et al. [28] observed that during the continuous heating process, large-sized MnS inclusions in non-quenched and tempered steel underwent spheroidization and coarsening processes. In linepipe steels [29], calcium aluminates were found to transform to $\mathrm{CaS}-\mathrm{Al}_{2} \mathrm{O}_{3}$ during heat treatment at $1473 \mathrm{~K}\left(1200^{\circ} \mathrm{C}\right)$, with a kinetic analysis based on solid-state diffusion. In previous work by one of the authors [30,31], solid-state reactions between 
Table 1. Chemical composition of the steel samples for the heat treatment experiments (values for $\mathrm{Mg}, \mathrm{Ca}$, and $\mathrm{O}$ were estimated from the inclusion composition and amounts).

\begin{tabular}{lllllllll}
\hline \multicolumn{7}{c}{ Chemical composition/mass\% } \\
\hline $\mathrm{C}$ & $\mathrm{Mn}$ & $\mathrm{P}$ & $\mathrm{S}$ & $\mathrm{Si}$ & $\mathrm{Mg}$ & $\mathrm{Al}$ & $\mathrm{Ca}$ & $\mathrm{O}(\mathrm{ppm})$ \\
0.2 & 0.7 & 0.01 & 0.005 & 0.2 & 0.0003 & 0.0379 & 0.0025 & 20 \\
\hline
\end{tabular}

Fe-Al-Ca alloy and $\mathrm{Al}_{2} \mathrm{O}_{3}-\mathrm{CaO}-\mathrm{FeO}$ oxide during heat treatment at $1473 \mathrm{~K}\left(1200^{\circ} \mathrm{C}\right)$ were studied. Heat treatment led to the decrease of $\mathrm{Al}$ content and increase of $\mathrm{Ca}$ content in the alloy. Some $\mathrm{Al}_{2} \mathrm{O}_{3}$ particles and $\mathrm{CaO} \cdot \mathrm{Al}_{2} \mathrm{O}_{3}$ dendritic inclusions precipitated as reaction products in the alloy near the alloy-oxide interface.

Previous studies have confirmed that inclusion characteristics can be modified by heat treatment when all phases are in the solid state. The steels studied here contained $50 \mathrm{ppm} \mathrm{S}$, were Al-killed, and were slightly overtreated with $\mathrm{Ca}$, resulting in excess CaS. However, characteristic transformation of inclusions in the steel during subsequent heat treatment is still unknown, which is essential for hot rolling process and control of steel product quality. In this work, isothermal heat treatment has been carried out at different temperatures in the range of 1373 to $1573 \mathrm{~K}$ (1100 to $1300^{\circ} \mathrm{C}$ ) under an argon atmosphere, and the resulting changes in morphology, composition, size distribution of the inclusions were subsequently analyzed by scanning electron microscopy (SEM) and energy dispersive spectrometer (EDS) using an ASPEX Explorer instrument. At relatively higher heat treatment temperatures (1473 and $1573 \mathrm{~K}$ (1200 and $\left.1300^{\circ} \mathrm{C}\right)$ ), the two main kinds of inclusions initially in the steels, $\mathrm{CaS}$ and $\mathrm{MgO}-\mathrm{Al}_{2} \mathrm{O}_{3}-\mathrm{CaO}-\mathrm{CaS}$, gradually transformed to (Ca, $\mathrm{Mn}) \mathrm{S}$ and $\mathrm{MgO}-\mathrm{Al}_{2} \mathrm{O}_{3}-(\mathrm{Ca}, \mathrm{Mn}) \mathrm{S}$ inclusions, respectively, and some $\mathrm{MgO}-\mathrm{Al}_{2} \mathrm{O}_{3}-\mathrm{CaO}$ inclusions also transformed to $\mathrm{MgO}-\mathrm{Al}_{2} \mathrm{O}_{3}-(\mathrm{Ca}, \mathrm{Mn}) \mathrm{S}$, while little evidence of transformation was observed at $1373 \mathrm{~K}\left(1100^{\circ} \mathrm{C}\right)$. The extent of transformation increased with decreasing inclusion size and higher temperature.

\section{Experimental method}

Steel samples were initially taken from the tundish during industrial production. The steel chemical composition listed in Table 1 was measured by inductively coupled plasma mass spectrometry (ICP-MS), combustion analysis (for $\mathrm{S}$ ) and inert gas fusion (for $\mathrm{O}$ ). $\mathrm{Ca}, \mathrm{Mg}$, and $\mathrm{O}$ bound in the inclusions were quantified from inclusion analysis and considered as the total $\mathrm{Ca}, \mathrm{Mg}$, and $\mathrm{O}$ in the steel, since the dissolved $\mathrm{Ca}, \mathrm{Mg}$, and $\mathrm{O}$ concentrations were extremely low. Values for $\mathrm{Ca}, \mathrm{Mg}$, and $\mathrm{O}$ were estimated based on the composition and amount of the inclusions measured by SEM/EDS with ASPEX Explorer instrument. The area fraction of inclusions was assumed to be volume fraction. The densities of steel and inclusion were assumed to be 7500 and $3500 \mathrm{~kg} \cdot \mathrm{m}^{-3}$, respectively. The total $\mathrm{Ca}, \mathrm{Mg}$ and $\mathrm{O}$ contents can be calculated by the following equations

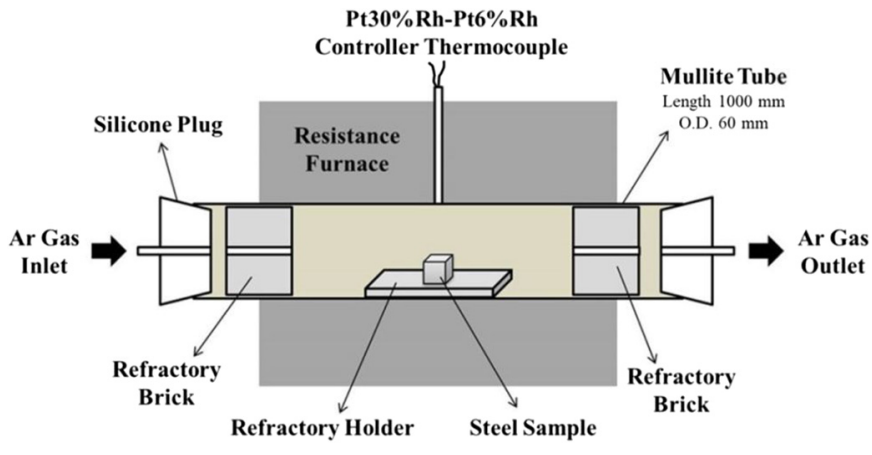

Fig. 1. Schematic of apparatus setup for heating experiment.

based on the measured average inclusion compositions.

$$
W_{\text {in steel }}=\frac{\rho_{\text {inclusion }}}{\rho_{\text {steel }}} \cdot \frac{\text { Area }_{\text {inclusion }}}{\text { Area }_{\text {steel }}} \cdot W_{\text {in inclusion }},
$$

where, $W_{\text {in steel }}$ represents the total estimated content of element $i$ in the steel, $\rho_{\text {inclusion }}$ and $\rho_{\text {steel }}$ are the densities of the inclusion and the steel, Area $a_{\text {inclusion }}$ and $A r e a_{\text {steel }}$ are the total measured areas of the inclusions and steel, respectively, $W_{\text {in inclusion }}$ represents the measured average content of element $\mathrm{i}$ in the inclusions. Each sample was machined into a cube approximately $10 \times 10 \times 10 \mathrm{~mm}$. Those steel samples were heat treated at 1373,1473 , and $1573 \mathrm{~K}\left(1100,1200\right.$, and $\left.1300{ }^{\circ} \mathrm{C}\right)$, respectively, for $3 \mathrm{~h}$. The heating and cooling rates were $4 \mathrm{~K} \cdot \mathrm{min}^{-1}$. Flowing Ar gas was used during the heating, isothermal hold, and cooling periods. A schematic of the setup is shown in Figure 1.

The steel samples after heat treatment were mounted in epoxy resin, ground with $320,800,1200$ and 2000 grit $\mathrm{SiC}$ papers, and then mirror polished with a $1 \mu \mathrm{m}$ diamond suspension. The chemical composition and size distributions of inclusions were measured on metallographically polished samples by SEM/EDS with a Thermo-Fisher/FEI/ASPEX Explorer instrument, operated at an acceleration voltage of $10 \mathrm{kV}$ with $5-7 \%$ brightness and $100 \%$ contrast. The spatial resolution of the microscope using backscattered electron imaging was measured to be approximately $0.4 \mu \mathrm{m}$ under those conditions. The area for analysis was at least $21 \mathrm{~mm}^{2}$ for each sample to acquire sufficient data. During microanalysis, the electron beam was rastered over the total exposed area of each inclusion to determine its average composition. Equilibrium thermodynamic calculations were performed with FactSage v. 7.2. The FToxid database was used for the slag, sulfide, and spinel oxide solutions. FactPS was used for the pure oxide inclusions and FSstel was used for the steel solid and liquid phases. 


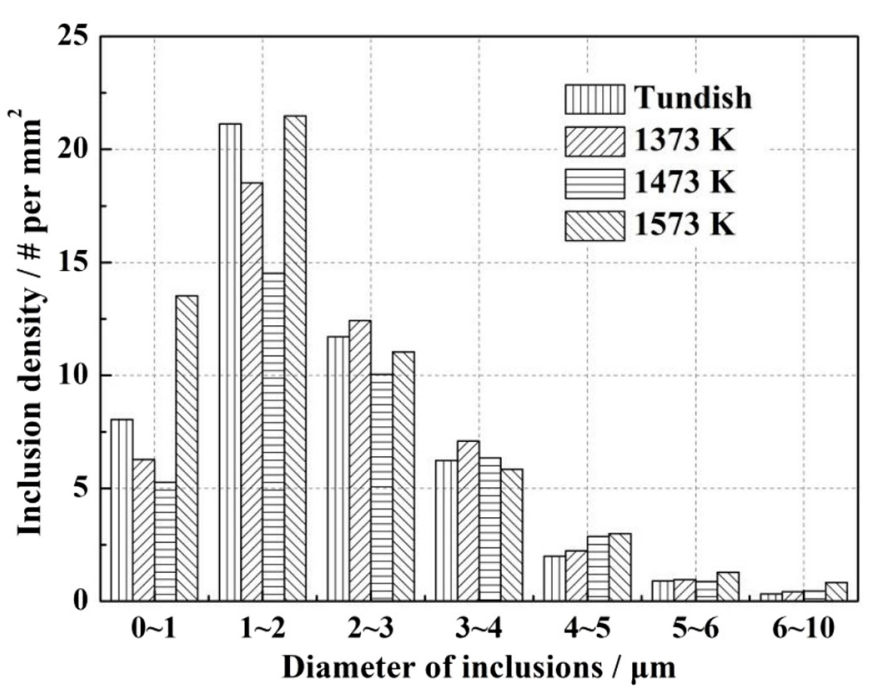

Fig. 2. Size distributions of total inclusions in the steels before and after the heat treatment at 1373, 1473, and $1573 \mathrm{~K}$ (1100, 1200 , and $1300^{\circ} \mathrm{C}$ ).

\section{Results}

Figure 2 shows the size distributions of total inclusions in the steel samples before and after heat treatment at 1373, 1473 , and $1573 \mathrm{~K}\left(1100,1200\right.$, and $\left.1300^{\circ} \mathrm{C}\right)$. Inclusion sizes in all cases mainly located in the range of 0 to $3 \mu \mathrm{m}$. Almost no inclusions with diameters greater than $10 \mu \mathrm{m}$ were found in these steel samples. The size distributions and total numbers of inclusions did not change noticeably during heat treatment, especially for the ones whose diameters larger than $2 \mu \mathrm{m}$.

Figure 3 shows the evolution of average composition, number density, average diameter, and area fraction of inclusions in steel samples before and after heat treatment at 1373,1473 , and $1573 \mathrm{~K}\left(1100,1200\right.$, and $\left.1300^{\circ} \mathrm{C}\right)$. The average composition of inclusions in steel samples changed significantly as the heat treatment temperature increased, as shown in Figure 3a; the contents of $\mathrm{Mn}$ and Ca increased and decreased, respectively, while those of $\mathrm{Al}, \mathrm{Mg}$ and $\mathrm{S}$ relatively remained stable. The number density, average diameter, and area fraction of inclusions in the steel before and after heat treatment at different temperatures are shown in Figure 3b through 3d. There are no significant changes in number density and area fraction of the measured inclusions after the heating, which demonstrates that during the heating process, good Ar gas protection was
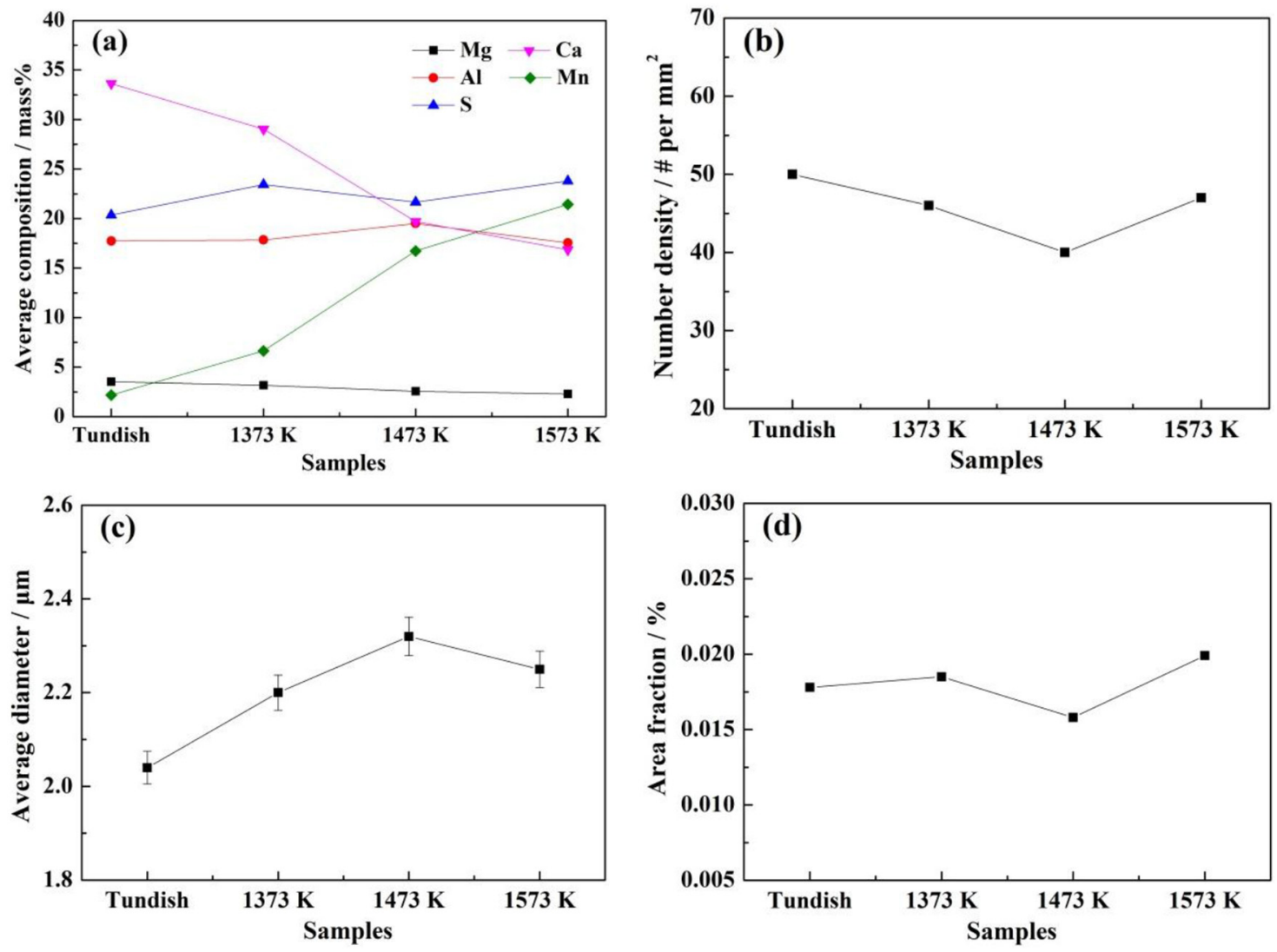

Fig. 3. Evolution of (a) average composition; (b) number density; (c) average diameter; and (d) area fraction of inclusions in steel samples before and after heat treatment at different temperatures. 


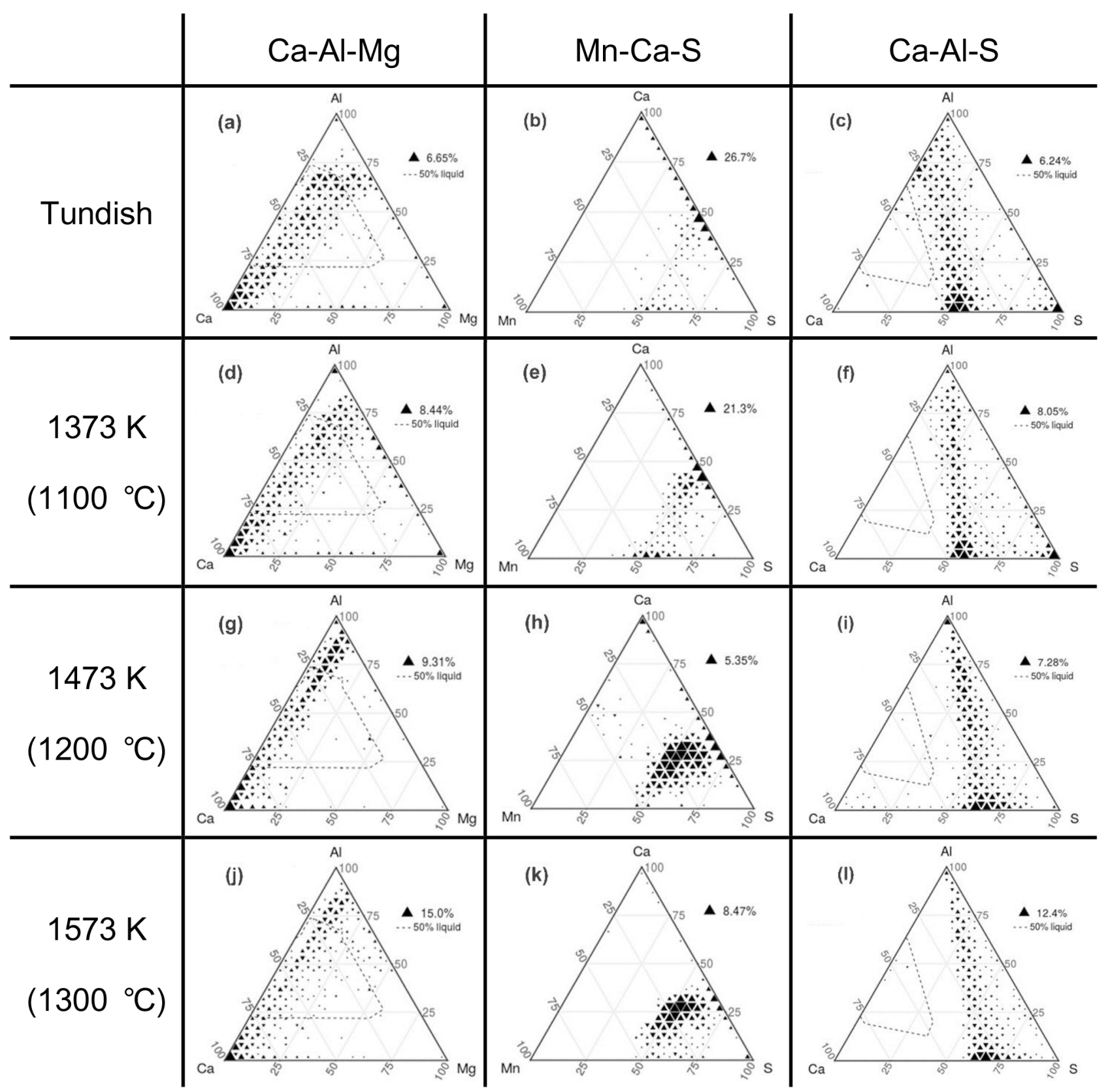

Fig. 4. Chemical compositions (mole fraction) of inclusions in tundish and after heat treatments. In each diagram the symbol size is proportional to the number fraction of inclusions with that composition. When indicated, the dashed line represents the region in which $50 \%$ of the inclusions would be liquid according to the equilibrium phase diagram.

achieved and there is no obvious oxidation of the steel. However, the average size of inclusions increased after the heating, which may be related to the transformation of the inclusions. When the steels were heated at 1373,1473 , and $1573 \mathrm{~K}\left(1100,1200\right.$, and $\left.1300^{\circ} \mathrm{C}\right)$, interfacial reactions between the inclusions and steels would occur, which resulted in changes of average inclusion composition and diameter.

Figure 4 shows the inclusion compositions (mole fraction) on the $\mathrm{Mg}-\mathrm{Al}-\mathrm{Ca}, \mathrm{S}-\mathrm{Ca}-\mathrm{Mn}$ and $\mathrm{S}-\mathrm{Al}-\mathrm{Ca}$ ternary diagrams from tundish samples and after three hours of heat treatment at the temperatures of 1373,1473 , and $1573 \mathrm{~K}\left(1100,1200\right.$, and $\left.1300^{\circ} \mathrm{C}\right)$. In the Figure 4 plots, the symbol size is proportional to the number fraction of inclusions of the indicated composition, and the area inside dashed line refers to a region at $1873 \mathrm{~K}\left(1600^{\circ} \mathrm{C}\right)$ where the fraction of liquid phase inclusions should be at least 0.5 .

As shown in Figures $4 \mathrm{a}$ and $4 \mathrm{~b}$, the main inclusions from the tundish sample were complex $\mathrm{MgO}-\mathrm{Al}_{2} \mathrm{O}_{3}-\mathrm{CaO}-$ $\mathrm{CaS}$ and pure CaS. Since there is no $\mathrm{S}$ element in the ternary diagram of $\mathrm{Ca}-\mathrm{Al}-\mathrm{Mg}$, standalone $\mathrm{CaS}$ inclusions mainly locate around the $\mathrm{Ca}$ component, as shown in 

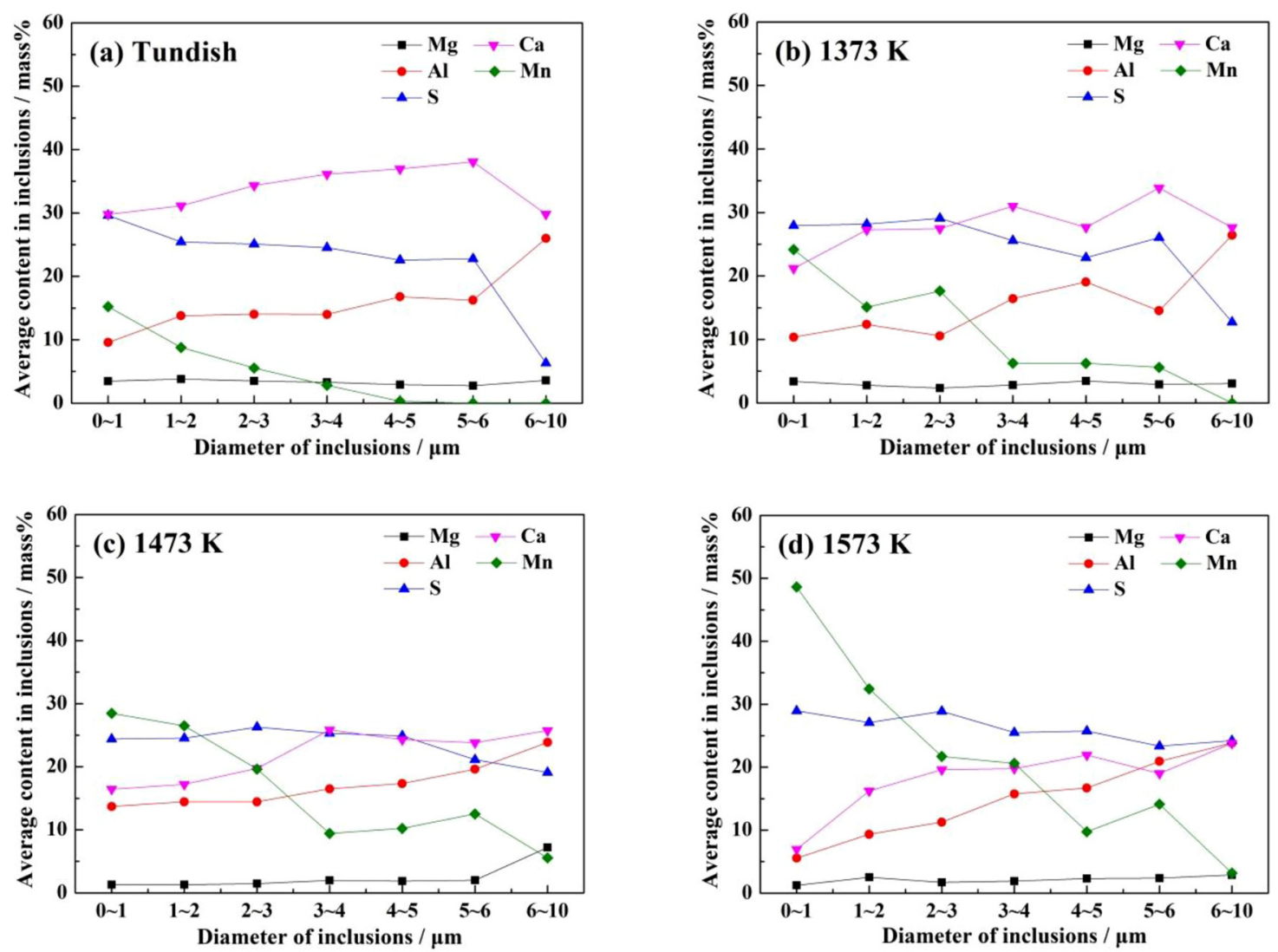

Fig. 5. Change in the average composition (mass \%) of inclusions with various apparent sizes in the steels (a) in tundish and after heat treatment at (b) $1373 \mathrm{~K}\left(1100^{\circ} \mathrm{C}\right) ;(\mathrm{c}) 1473 \mathrm{~K}\left(1200^{\circ} \mathrm{C}\right)$ and; (d) $1573 \mathrm{~K}\left(1300^{\circ} \mathrm{C}\right)$.

Figures 4a, 4d, 4g and 4j. Figure 4c shows that besides $\mathrm{MgO}-\mathrm{Al}_{2} \mathrm{O}_{3}-\mathrm{CaO}-\mathrm{CaS}$ and pure $\mathrm{CaS}$ inclusions, some complex $\mathrm{MgO}-\mathrm{Al}_{2} \mathrm{O}_{3}-\mathrm{CaO}$ inclusions without $\mathrm{S}$ also formed in the tundish sample. Comparison of Figures $4 \mathrm{a}$ and $4 \mathrm{~b}$ with $4 \mathrm{~d}$ and $4 \mathrm{e}$ shows that little change was observed after heat treatment at $1373 \mathrm{~K}\left(1100^{\circ} \mathrm{C}\right)$. However, as shown in Figure 4f, it is noted that almost no $\mathrm{MgO}-\mathrm{Al}_{2} \mathrm{O}_{3}-\mathrm{CaO}$ inclusions were observed in the sample after heating at $1373 \mathrm{~K}\left(1100^{\circ} \mathrm{C}\right)$. After heat treatment at the higher temperatures, $\mathrm{MgO}$ content decreased and $\mathrm{Al}_{2} \mathrm{O}_{3}$ content increased in the complex $\mathrm{MgO}-\mathrm{Al}_{2} \mathrm{O}_{3}-$ $\mathrm{CaO}-\mathrm{CaS}$ inclusions. Tighter distribution of the inclusions shown in the $\mathrm{Mg}-\mathrm{Al}-\mathrm{Ca}$ ternary diagram at higher heat treatment temperature was obtained, as shown in Figures $4 \mathrm{~g}$ and $4 \mathrm{j}$.

Also after heat treatment at 1473 and $1573 \mathrm{~K}$ (1200 and $1300^{\circ} \mathrm{C}$ ), a more noteworthy phenomenon was that $\mathrm{Mn}$ contents in the $\mathrm{CaS}$ and complex $\mathrm{MgO}-\mathrm{Al}_{2} \mathrm{O}_{3}-\mathrm{CaO}-\mathrm{CaS}$ inclusions, shown in Figures $4 \mathrm{~h}$ and $4 \mathrm{k}$, significantly increased. In the $\mathrm{S}-\mathrm{Al}-\mathrm{Ca}$ ternary diagram shown in Figures $4 \mathrm{i}$ and 4l, the molar ratio of sulfur to calcium in the inclusions increased as the MnS content of the inclusions increased after heat treatment.

Figure 5 shows the change in the average composition (mass \%) of inclusions with various apparent diameters in the steels in tundish and after the heat treatment. The average composition of inclusions with various inclusion sizes was obtained by equation (2):

$$
j_{\text {avg }}=\frac{\sum_{k=1}^{n} j_{k} \times \text { Area }_{k}}{\sum_{k=1}^{n} \text { Area }_{k}},
$$

where $j_{a v g}$ is the average composition of inclusions in a certain size range, $j_{k}$ and $A r e a_{k}$ indicate the composition and apparent area of a single inclusion $k, n$ is the inclusion number in the certain size range. In this study, the apparent diameters of the inclusions ranged from $0 \sim 1$ to $6 \sim 10 \mu \mathrm{m}$. Experimental results indicated that after heat treatment, the inclusions with smaller apparent diameters contained higher $\mathrm{Mn}$ and $\mathrm{S}$ contents as well as lower $\mathrm{Ca}$ content.

According to Figure 4, standalone CaS and complex oxide-sulfide inclusions were present in the liquid steel. Figure 6 shows the morphology and measured element distribution of a standalone $\mathrm{CaS}$ inclusion before and after heat treatment at $1473 \mathrm{~K}\left(1200^{\circ} \mathrm{C}\right)$.

Transformations of complex $\mathrm{MgO}-\mathrm{Al}_{2} \mathrm{O}_{3}-\mathrm{CaO}$ and $\mathrm{MgO}-\mathrm{Al}_{2} \mathrm{O}_{3}-\mathrm{CaO}-\mathrm{CaS}$ inclusions also were observed after heat treatment. A typical oxide + sulfide inclusion from the tundish sample is shown in Figure 7a. Spherical oxide inclusions were also observed as shown in Figure $7 \mathrm{~b}$. Figure $7 \mathrm{c}$ shows a typical oxide + sulfide inclusion after heat treatment. No standalone $\mathrm{MgO}-\mathrm{Al}_{2} \mathrm{O}_{3}-\mathrm{CaO}$ oxide inclusions were observed after heat treatment. 

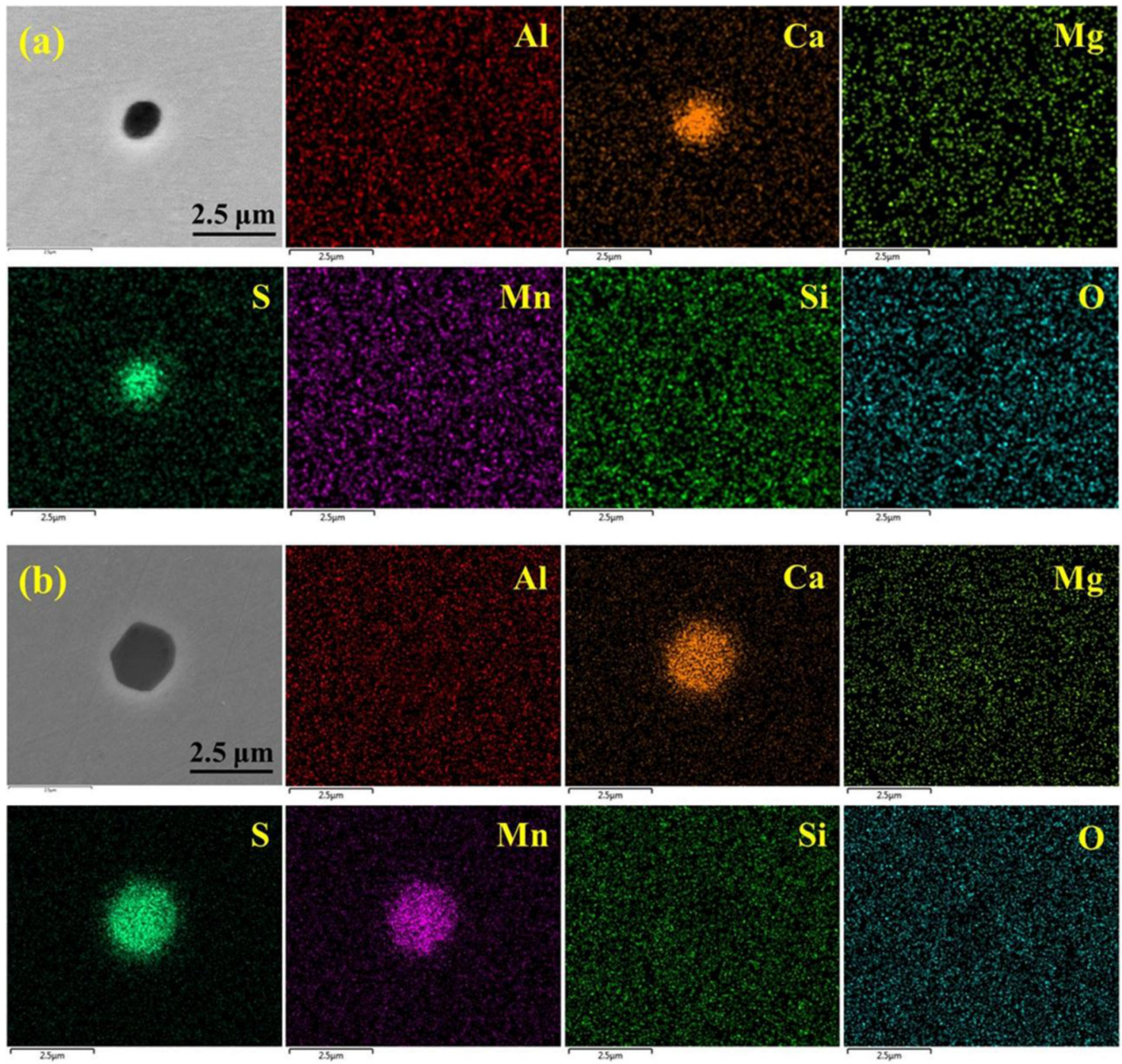

Fig. 6. Morphology and measured element distribution of typical inclusions in the steels: (a) CaS in the tundish sample; (b) (Ca, Mn)S in the sample after heat treatment at $1473 \mathrm{~K}\left(1200^{\circ} \mathrm{C}\right)$.

\section{Discussion}

In this study, two main kinds of initial standalone inclusions were found in the tundish sample, $\mathrm{CaS}$ and $\mathrm{MgO}-\mathrm{Al}_{2} \mathrm{O}_{3}-\mathrm{CaO}-\mathrm{CaS}$ inclusions, as well as some spherical $\mathrm{MgO}-\mathrm{Al}_{2} \mathrm{O}_{3}-\mathrm{CaO}$ inclusions. After the heat treatment at 1373,1473 and $1573 \mathrm{~K}\left(1100,1200\right.$ and $\left.1300^{\circ} \mathrm{C}\right)$, typical oxide + sulfide inclusions and sulfide inclusions were observed in steels, without standalone $\mathrm{MgO}-\mathrm{Al}_{2} \mathrm{O}_{3}-\mathrm{CaO}$ oxide inclusions. Although the size distribution and total number of inclusions did not change noticeably during heat treatment, with higher heating temperature, Mn content increased and $\mathrm{Ca}$ content decreased in the inclusions, especially for those smaller ones. This indicated more extensive transformation of smaller $\mathrm{CaS}, \mathrm{MgO}-\mathrm{Al}_{2} \mathrm{O}_{3}-$ $\mathrm{CaO}-\mathrm{CaS}$ and $\mathrm{MgO}-\mathrm{Al}_{2} \mathrm{O}_{3}-\mathrm{CaO}$ inclusions. However, those phenomena were restrained during the heating at $1373 \mathrm{~K}\left(1100^{\circ} \mathrm{C}\right)$.
Predicted equilibrium inclusion phases in the steel with the temperature were calculated by FactSage 7.2, as shown in Figure 8. Calculations in Figure 8a indicated that $\mathrm{MgO}-\mathrm{Al}_{2} \mathrm{O}_{3}-\mathrm{CaO}$ liquid oxide and solid $\mathrm{CaS}$ inclusions would be stable in the liquid steel. A single sulfide solid solution (Ca, Mn)S formed at high temperature, but a miscibility gap occurred in the Ca$\mathrm{Mn}-\mathrm{S}$ system at approximately $1573 \mathrm{~K}\left(1300^{\circ} \mathrm{C}\right)[32-34]$. Figures $8 \mathrm{~b}$ and $8 \mathrm{c}$ show the change of component amounts in the two sulfide phases (MS-c\#1 and MSc\#2) as a function of temperature.

A comparison of predicted equilibrium inclusion compositions and measured compositions is given in Figure 9. It was clear that reaction with the steel occurred, even though the equilibrium compositions were not reached. In addition, as the heating temperature increased, especially at 1473 and $1573 \mathrm{~K}$ (1200 and $1300{ }^{\circ} \mathrm{C}$ ), the measured inclusion compositions gradually became close to the predicted equilibrium compositions. 

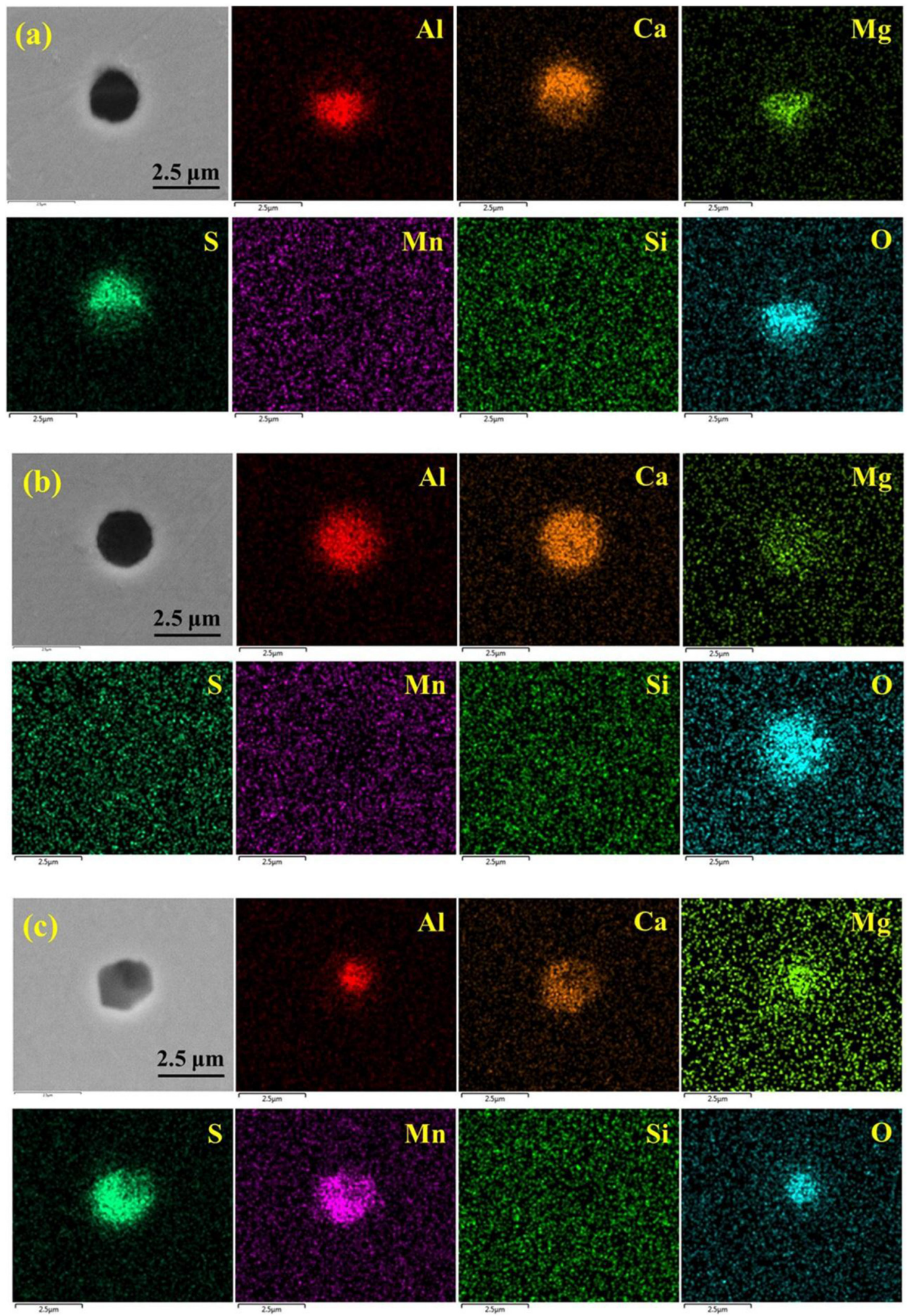

Fig. 7. Morphology and measured element distribution of typical inclusions in the steels: (a) $\mathrm{MgO}-\mathrm{Al}_{2} \mathrm{O}_{3}-\mathrm{CaO}-\mathrm{CaS}$ in the tundish sample; (b) $\mathrm{MgO}-\mathrm{Al}_{2} \mathrm{O}_{3}-\mathrm{CaO}$ in the tundish sample; and (c) $\mathrm{MgO}-\mathrm{Al}_{2} \mathrm{O}_{3}-(\mathrm{Ca}, \mathrm{Mn}) \mathrm{S}$ in the sample after heat treatment at $1473 \mathrm{~K}$ $\left(1200^{\circ} \mathrm{C}\right)$. 

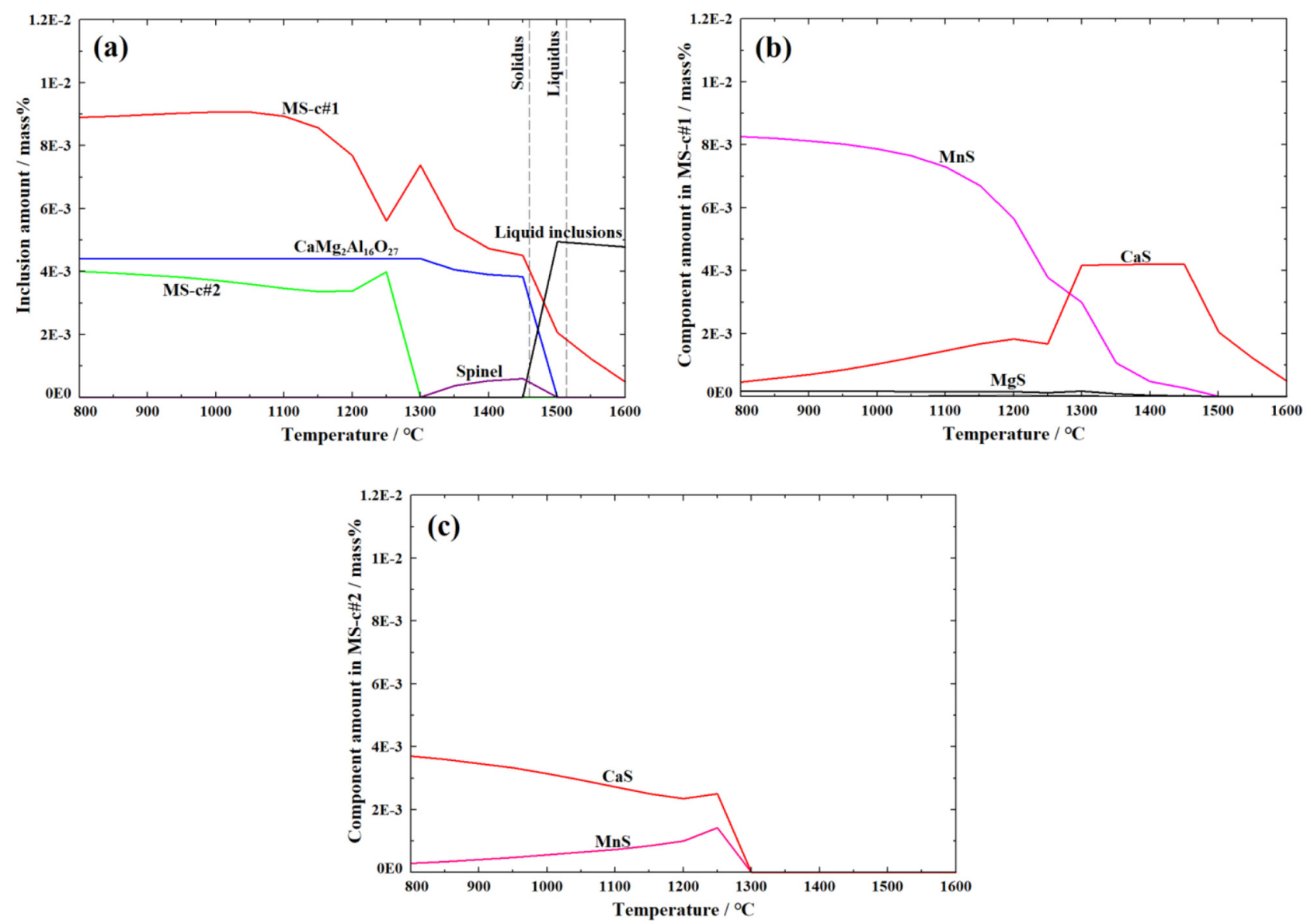

Fig. 8. Predicted equilibrium inclusion phases in the steel with the temperature: (a) predicted equilibrium inclusion phases; component amount in the (b) MS-c\#1 phase and (c) MS-c\#2 phase.

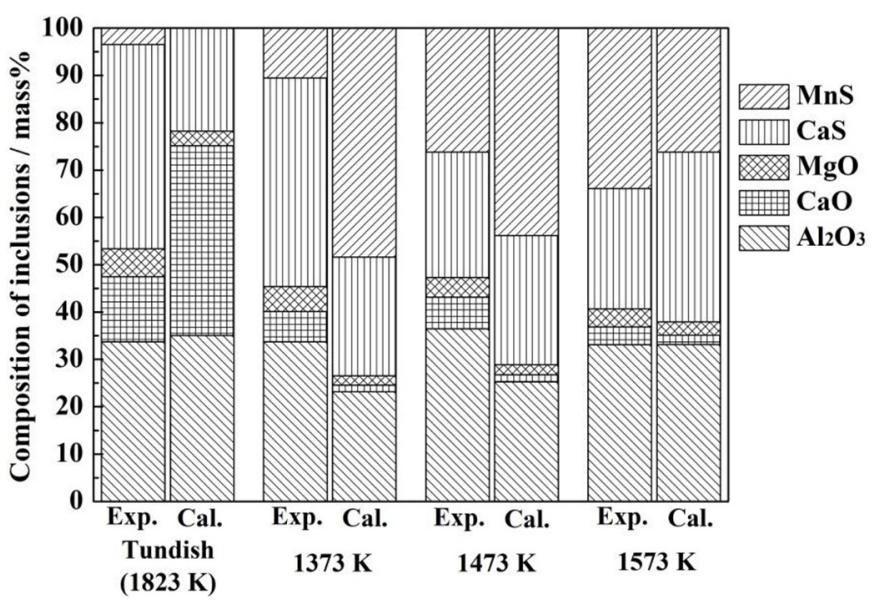

Fig. 9. Comparisons of experimental results and predicted equilibrium inclusion compositions before and after the heat treatment.

Further support for reaction with the steel can be seen in Figure 5, which showed more extensive composition changes for smaller inclusions. This was expected because supply of species like $\mathrm{Mn}$ and $\mathrm{S}$ should be limited by diffusion in the steel, so the flux should be larger as particle size decreased.
As noted in Figures 6 and 7, there were three different inclusion types observed in the tundish sample: standalone sulfides (CaS), oxide-sulfide $\left(\mathrm{MgO}-\mathrm{Al}_{2} \mathrm{O}_{3}-\mathrm{CaO}-\mathrm{CaS}\right)$, and standalone oxides $\left(\mathrm{MgO}-\mathrm{Al}_{2} \mathrm{O}_{3}-\mathrm{CaO}\right)$. Figure 10 shows the transformation of each type schematically. The standalone sulfide inclusions transformed to $(\mathrm{Ca}, \mathrm{Mn}) \mathrm{S}$ solutions due to the reaction with $[\mathrm{Mn}]$ and $[\mathrm{S}]$ in the steel. The evolution of the oxide + sulfide inclusions was similar, with the initially CaS part of the inclusions reacting with $\mathrm{Mn}$ and $\mathrm{S}$ in the steel. This led to the oxide $+(\mathrm{Ca}, \mathrm{Mn}) \mathrm{S}$ inclusions shown in Figure 7c.

Some of the oxide inclusions initially contained no sulfide phase, but after heat treatment no standalone oxide inclusions were observed. Other work has observed transformation of the $\mathrm{CaO}$ component to $\mathrm{CaS}$ after heat treatment via the reaction (3) $[14,29,35-38]$. It was thought that during the heating at 1373,1473 , and $1573 \mathrm{~K}(1100$, 1200 , and $1300^{\circ} \mathrm{C}$ ) for $3 \mathrm{~h}$, the reaction between [Al] and $\mathrm{CaO}$ firstly occurred, resulting in an increase of $\mathrm{Al}_{2} \mathrm{O}_{3}$ in inclusions, and then the reaction between $[\mathrm{S}]$ and $\mathrm{CaO}$ occurred leading to an increase of $\mathrm{CaS}$ content in the inclusions, although this reaction was commonly observed in molten steel and during steel solidification.

$$
\begin{aligned}
& 3(\mathrm{CaO})_{\text {in inclusions }}+3[\mathrm{~S}]+2[\mathrm{Al}] \\
& \quad=3(\mathrm{CaS})+\left(\mathrm{Al}_{2} \mathrm{O}_{3}\right)_{\text {in inclusions }} .
\end{aligned}
$$


(a)

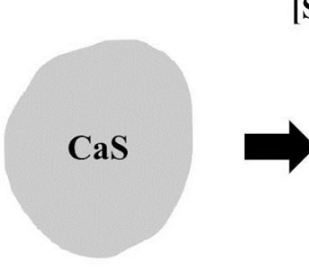

Before heat treatment
$[\mathrm{S}],[\mathrm{Mn}]$ in the steel

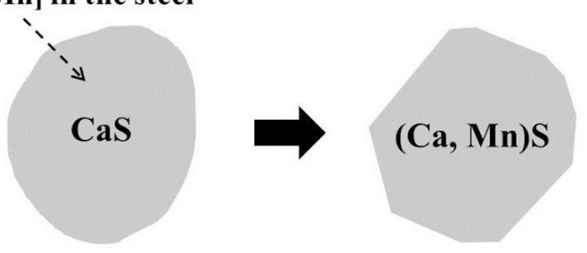

During heat treatment (b)

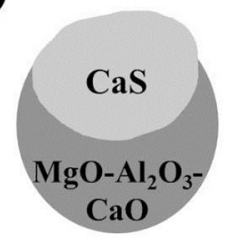

Before heat treatment
$[\mathrm{S}],[\mathrm{Mn}]$ in the steel

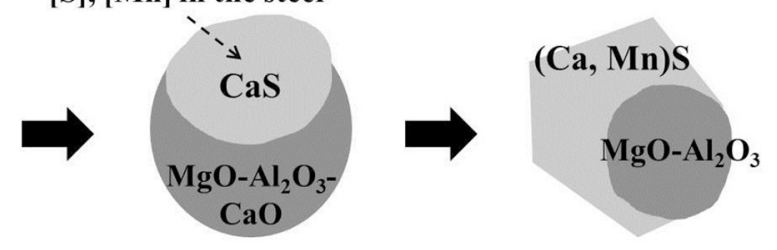

During heat treatment
After heat treatment (c)

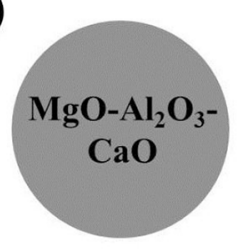

Before heat treatment
$[\mathrm{Al}],[\mathrm{S}]$ in the steel

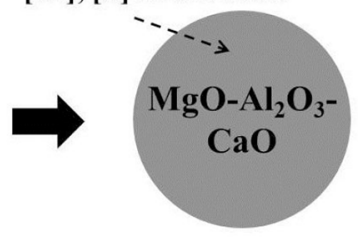

During heat treatment
$[\mathrm{S}],[\mathrm{Mn}]$ in the steel

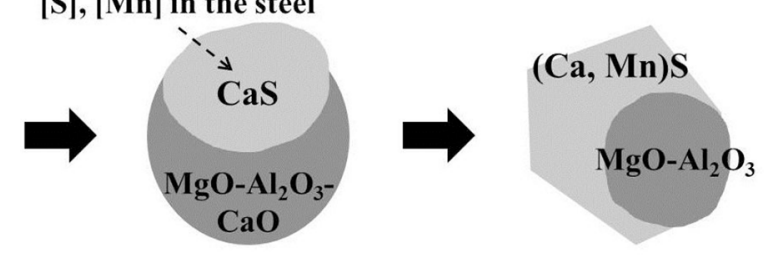

During heat treatment

After heat treatment

Fig. 10. Schematic of the transformation mechanism of (a) $\mathrm{CaS}$; (b) $\mathrm{MgO}-\mathrm{Al}_{2} \mathrm{O}_{3}-\mathrm{CaO}-\mathrm{CaS}$ and; (c) $\mathrm{MgO}-\mathrm{Al}_{2} \mathrm{O} 3-\mathrm{CaO}$ inclusions during the heat treatment of steels.

Then dissolved [Mn] would react with $\mathrm{CaS}$ and lead to the formation of complex $\mathrm{MgO}-\mathrm{Al}_{2} \mathrm{O}_{3}-(\mathrm{Ca}, \mathrm{Mn}) \mathrm{S}$ inclusions [39], as shown in Figures $7 \mathrm{~b}$ and $7 \mathrm{c}$. The sequence of chemistry changes should be $\mathrm{MgO}-\mathrm{Al}_{2} \mathrm{O}_{3}-\mathrm{CaO} \rightarrow \mathrm{MgO}-$ $\mathrm{Al}_{2} \mathrm{O}_{3}-\mathrm{CaO}-\mathrm{CaS} \rightarrow \mathrm{MgO}-\mathrm{Al}_{2} \mathrm{O}_{3}-(\mathrm{Ca}, \mathrm{Mn}) \mathrm{S}$. Morphology of the $(\mathrm{Ca}, \mathrm{Mn}) \mathrm{S}$ phase in the $\mathrm{MgO}-\mathrm{Al}_{2} \mathrm{O}_{3}-(\mathrm{Ca}, \mathrm{Mn}) \mathrm{S}$ inclusions also shows angular shape. It was also noted that the morphology of the inclusion became angular after the heat treatment.

\section{Conclusions}

In the present study, heat treatment experiments have been conducted to study the transformation mechanism of inclusions in the steels at different temperatures in the range of 1373 to $1573 \mathrm{~K}\left(1100\right.$ to $\left.1300^{\circ} \mathrm{C}\right)$. The conclusions are as follows:

During the heat treatment at 1473 and $1573 \mathrm{~K}$ (1200 and $1300^{\circ} \mathrm{C}$ ), two main kinds of inclusions in the steels, $\mathrm{CaS}$ and $\mathrm{MgO}-\mathrm{Al}_{2} \mathrm{O}_{3}-\mathrm{CaO}-\mathrm{CaS}$ inclusions, gradually transformed to $(\mathrm{Ca}, \mathrm{Mn}) \mathrm{S}$ and $\mathrm{MgO}-\mathrm{Al}_{2} \mathrm{O}_{3}-(\mathrm{Ca}, \mathrm{Mn}) \mathrm{S}$ inclusions, respectively, and some $\mathrm{MgO}-\mathrm{Al}_{2} \mathrm{O}_{3}-\mathrm{CaO}$ inclusions also transformed to $\mathrm{MgO}-\mathrm{Al}_{2} \mathrm{O}_{3}-(\mathrm{Ca}, \mathrm{Mn}) \mathrm{S}$ inclusions, while those phenomena were restrained during the heating at $1373 \mathrm{~K}\left(1100{ }^{\circ} \mathrm{C}\right)$.
No significant changes in number density and area fraction of the measured inclusions were observed, while the average size of inclusions increased after the heat treatment.

The transformation extents of CaS, $\mathrm{MgO}-\mathrm{Al}_{2} \mathrm{O}_{3}-\mathrm{CaO}-$ $\mathrm{CaS}$ and $\mathrm{MgO}-\mathrm{Al}_{2} \mathrm{O}_{3}-\mathrm{CaO}$ inclusions generally have a negative correlation with inclusion size, and a positive correlation with heat treatment temperature, in the range of 1373 to $1573 \mathrm{~K}$ (1100 to $1300^{\circ} \mathrm{C}$ ). With higher heating temperature, the measured inclusion compositions gradually became closer to the predicted equilibrium compositions.

Acknowledgment. The authors acknowledge support from the member companies of the Center for Iron and Steelmaking Research and the International Postdoctoral Exchange Fellowship Program (2017) by China Postdoctoral Council as well as use of the Materials Characterization Facility at Carnegie Mellon, supported by grant MCF-677785.

\section{References}

1. N.G. Kolbasnikov, M.A. Matveev, P.A. Mishnev, Effect of structure factor on high-temperature ductility of pipe steels, Met. Sci. Heat Treat. 58(1-2), 51-57 (2016)

2. B.T. Lu, J.L. Luo, Crack initiation and early propagation of $\mathrm{X} 70$ steel in simulated near-neutral $\mathrm{pH}$ groundwater, Corrosion 62(8), 723-731 (2006) 
3. T. Hara, H. Asahi, H. Ogawa. Conditions of hydrogeninduced corrosion occurrence of X65 grade line pipe steels in sour environments, Corrosion 60(12), 1113-1121 (2004)

4. B. Beidokhti, A. Dolati, A.H. Koukabi. Effects of alloying elements and microstructure on the susceptibility of the welded HSLA steel to hydrogen-induced cracking and sulfide stress cracking, Mater. Sci. Eng. A. 507(1-2), 167-173 (2009)

5. A. Takahashi, H. Ogawa. Influence of microhardness and inclusion on stress oriented hydrogen induced cracking of line pipe steels, ISIJ Int. 36(3), 334-340 (1996)

6. Y.F. Sui, C.S. Yue, B. Peng, et al., Optimization of slag chemistry toward inclusion control for $28 \mathrm{CrMo} 47$ drill pipe steel based on viscosity and equilibration studies, Steel Res. Int. 87(6), 752-760 (2015)

7. N. Verma, P.C. Pistorius, R.J. Fruehan, et al., Transient inclusion evolution during modification of alumina inclusions by calcium in liquid steel: Part I. Background, experimental techniques and analysis methods, Metall. Mater. Trans. B. 42(4), 711-719 (2011)

8. M.M. Song, B. Song, S.H. Zhang, et al., Effect of heat input on microstructure and toughness of rare earth-contained C-Mn steel, J. Iron Steel Res. Int. 25(10), 1033-1042 (2018)

9. H. Zhang, C.S. Liu, Q. Lin, et al., Formation of plastic inclusions in U71Mnk high-speed heavy-rail steel refined by CaO- $\mathrm{SiO}_{2}-\mathrm{Al}_{2} \mathrm{O}_{3}-\mathrm{MgO}$ slag, Metall. Mater. Trans. B. 50(1), 459-470 (2019)

10. L.Z. Wang, S.F. Yang, J.S. Li, et al., Improving cleanliness of $95 \mathrm{CrMo}$ drill rod steel by slag refining, Metall. Mater. Trans. B. 47(1), 99-107 (2016)

11. H.Y. Mu, T.S. Zhang, R.J. Fruehan, et al., Reduction of $\mathrm{CaO}$ and $\mathrm{MgO}$ slag components by $\mathrm{Al}$ in liquid $\mathrm{Fe}$, Metall. Mater. Trans. B. 49(4), 1665-1674 (2018)

12. Y. Ren, Y.F. Wang, S.S. Li, et al., Detection of non-metallic inclusions in steel continuous casting billets, Metall. Mater. Trans. B. 45(4), 1291-1303 (2014)

13. J.J. Wang, W.F. Li, Y. Ren, et al., Thermodynamic and kinetic analysis for transformation of oxide inclusions in solid 304 stainless steels, Steel Res. Int. 90(7), 1800600 (2019)

14. Y. Wang, M. Valdez, S. Sridhar Formation of $\mathrm{CaS}$ on $\mathrm{Al}_{2} \mathrm{O}_{3}-$ $\mathrm{CaO}$ inclusions during solidification of steels, Metall. Mater. Trans. B. 33(4), 625-632 (2002)

15. S.K. Choudhary, A. Ghosh Mathematical model for prediction of composition of inclusions formed during solidification of liquid steel, ISIJ Int. 49(12), 1819-1827 (2009)

16. S.Y. Chen, X.D. Yue, G.C. Jin, et al., Behavior of inclusions in process of solid growth during solidification of Fe-0.15C0.8Mn steel, J. Iron Steel Res. Int. 19(5), 17 (2012)

17. M. Suzuki, R. Yamaguchi, K. Murakami, et al., Inclusion particle growth during solidification of stainless steel, ISIJ Int. 41(3), 247-256 (2001)

18. W. Chen, Y. Ren, L.F. Zhang, Large eddy simulation on the fluid flow, solidification and entrapment of inclusions in the steel along the full continuous casting slab strand, JOM. 70 (12), 2968-2979 (2018)

19. I. Takahashi, T. Sakae, T. Yoshida, Changes of the nonmetallic inclusion by heating, Tetsu-to-Hagané 53(3), 350-352 (1967)
20. H. Shibata, T. Tanaka, K. Kimura, et al., Composition change in oxide inclusions of stainless steel by heat treatment, Ironmak. Steelmak. 37(7), 522-528 (2010)

21. C.S. Liu, H.W. Ni, S.F. Yang, et al., Interfacial reaction mechanism between multi-component oxides and solid alloys deoxidized by $\mathrm{Mn}$ and Si during heat treatment, Ironmak. Steelmak. 45(3), 195-203 (2018)

22. W. Yang, C.B. Guo, C. Li, et al., Transformation of inclusions in pipeline steels during solidification and cooling, Metall. Mater. Trans. B. 48(5), 2267-2273 (2017)

23. Y. Wang, W. Yang, L.F. Zhang, Effect of cooling rate on oxide inclusions during solidification of 304 stainless steel, Steel Res. Int. 90(7), 1900027 (2019)

24. H. Shibata, K. Kimura, T. Tanaka, et al., Mechanism of change in chemical composition of oxide inclusions in $\mathrm{Fe}-\mathrm{Cr}$ alloys deoxidized with $\mathrm{Mn}$ and $\mathrm{Si}$ by heat treatment at 1473 K, ISIJ Int. 51(12), 1944-1950 (2011)

25. Y. Ren, L.F. Zhang, P.C. Pistorius, Transformation of oxide inclusions in type 304 stainless steels during heat treatment, Metall. Mater. Trans. B. 48(5), 2281-2292 (2017)

26. K.H. Kim, S.J. Kim, H. Shibata, et al., Reaction between $\mathrm{MnO}-\mathrm{SiO}_{2}-\mathrm{FeO}$ oxide and $\mathrm{Fe}-\mathrm{Mn}-\mathrm{Si}$ solid alloy during heat treatment, ISIJ Int. 54(10), 2144-2153 (2014)

27. W. Choi, H. Matsuura, F. Tsukihashi, Changing behavior of non-metallic inclusions in solid iron deoxidized by $\mathrm{Al}-\mathrm{Ti}$ addition during heating at $1473 \mathrm{~K}$, ISIJ Int. 51(12), 19511956 (2011)

28. X.J. Shao, X.H. Wang, M. Jiang, et al., Effect of heat treatment conditions on shape control of large-sized elongated MnS inclusions in resulfurized free-cutting steels, ISIJ Int. 51(12), 1995-2001 (2011)

29. Y.P. Chu, W.F. Li, Y. Ren, et al., Transformation of inclusions in linepipe steels during heat treatment, Metall. Mater. Trans. B. 50(4), 2047-2062 (2019)

30. C.S. Liu, S.F. Yang, J.S. Li, et al., Solid-state reaction between $\mathrm{Fe}-\mathrm{Al}-\mathrm{Ca}$ alloy and $\mathrm{Al}_{2} \mathrm{O}_{3}-\mathrm{CaO}-\mathrm{FeO}$ oxide during heat treatment at $1473 \mathrm{~K}\left(1200^{\circ} \mathrm{C}\right)$, Metall. Mater. Trans. B. 48(2), 1348-1357 (2017)

31. C.S. Liu, S.F. Yang, J.S. Li, et al., The influence of FeO on the reaction between $\mathrm{Fe}-\mathrm{Al}-\mathrm{Ca}$ alloy and $\mathrm{Al}_{2} \mathrm{O}_{3}-\mathrm{CaO}-\mathrm{FeO}$ oxide during heat treatment at $1473 \mathrm{~K}$, Metals 7(4), 129 (2017)

32. R. Kiessling, C. Westman, The MnS-CaS system and its metallurgical significance, J. Iron Steel Inst. 208(7), 699-700 (1970)

33. B.J. Skinner, F.D. Luce, Solid solutions of the type (Ca, Mg, $\mathrm{Mn}, \mathrm{Fe}) \mathrm{S}$ and their use as geothermometers for the enstatite chondrites, Am. Miner. 56(7-8), 1269-1276 (1971)

34. C.H. Leung, L.H.V. Vlack, Solubility limits in binary (Ca, Mn) Chalcogenides, J. Am. Ceram. Soc. 62(11-12), 613-621 (1979)

35. D.Z. Lu, G.A. Irons, W.K. Lu, Calculation of $\mathrm{CaS}$ and $\mathrm{MnS}$ activities and their application to calcium treatment of steel, Ironmak. Steelmak. 18(5), 342-346 (1991)

36. G. Xu, Z.H. Jiang, Y. Li, Formation mechanism of CaSbearing inclusions and the rolling deformation in Al-killed, low-alloy steel with Ca treatment, Metall. Mater. Trans. B. 47(4), 2411-2420 (2016)

37. J.F. Xu, F.X. Huang, X.H. Wang, Formation mechanism of $\mathrm{CaS}-\mathrm{Al}_{2} \mathrm{O}_{3}$ inclusions in low sulfur Al-killed steel after calcium treatment, Metall. Mater. Trans. B. 47(2), 12171227 (2016) 
38. W. Yang, L.F. Zhang, X.H. Wang, et al., Characteristics of inclusions in low carbon Al-killed steel during ladle furnace refining and calcium treatment, ISIJ Int. 53(8), 1401-1410 (2013)
39. R.X. Piao, H.G. Lee, Y.B. Kang, Activity measurement of the $\mathrm{CaS}-\mathrm{MnS}$ sulfide solid solution and thermodynamic modeling of the $\mathrm{CaO}-\mathrm{MnO}-\mathrm{Al}_{2} \mathrm{O}_{3}-\mathrm{CaS}-\mathrm{MnS}-\mathrm{Al}_{2} \mathrm{~S}_{3}$ system, ISIJ Int. 53(12), 2132-2141 (2013)

Cite this article as: Chengsong Liu, Bryan Webler, Evolution of non-metallic inclusions during heat treatment, Metall. Res. Technol. 117, $408(2020)$ 